\title{
O PROCESSO DE MUDANÇAS ADMINISTRATIVAS E TECNOLÓGICAS QUE PÔS FIM ÀS FILAS NOS POSTOS DE ATENDIMENTO DA PREVIDÊNCIA SOCIAL
}

\section{THE PROCESS OF ADMINISTRATIVE AND TECHNOLOGICAL CHANGES THAT PUTS AN END TO QUEUES IN OFFICES OF SOCIAL SECURITY}

\begin{abstract}
SIDNEY SOARES FILHO
Doutor e Mestre em Direito Constitucional pela Universidade de Fortaleza (Unifor), especialista em Direito Público com área de concentração em Direito Constitucional pela Universidade Potiguar (UnP) e em Direito Processual pela Universidade do Sul de Santa Catarina (Unisul); Professor da graduação e pós-graduação da Universidade de Fortaleza (Unifor); e de alguns cursos preparatórios para concurso público. Coordenador da Pós-Graduação em Direito e Processo Penal e em Direito e Processo Previdenciário. Analista Judiciário - Execução de Mandados (TJ/Ce) sid_filho@hotmail.com

\section{Robson CELSO Leocádio TOte Graduado em Ciências da Computação pela Universidade Estadual do Ceará (UECE) Bacharel em Direito pela Universidade de Fortaleza (UNIFOR) Especialista em Direito Previdenciário pela Universidade de Fortaleza (UNIFOR)} Analista de Tecnologia da Informação da Empresa de Tecnologia da Informação da Previdência Social (DATAPREV)
\end{abstract} robson.tote@gmail.com

\begin{abstract}
RESUMO
Este trabalho analisa o processo de mudança das filas de atendimento da Previdência Social na DATAPREV para a concessão dos benefícios previdenciários. Houve o fim das longas filas presenciais nos postos de benefícios, que eram divulgadas pelos meios de comunicação. O precário atendimento submetia o segurado à humilhação em filas que se iniciavam na madrugada. Partiu-se da análise do modelo de atendimento antigo, que convivia frequentemente com essas longas filas, na busca de estabelecer um cenário para aquela situação anterior, registrada especialmente nos anos noventa, a fim de entender o ponto de partida para a mudança. Em seguida, analisou-se como se deu esse processo de mudança e quais foram seus principais agentes. Finalmente, estudouse o modelo de atendimento atual. Fez-se uso de uma metodologia baseada em pesquisa bibliográfica, artigos, sítios digitais, jornais e entrevistas com profissionais que vivenciaram todo esse processo de mudança, além do uso de gráficos e tabelas. Conclui-se que o processo de mudança melhorou o atendimento da Previdência.
\end{abstract}

Palavras-chave: DATAPREV; Filas na Previdência Social; Postos de Benefícios.

\begin{abstract}
This paper analyzes the process of changing service queues Social Security in DATAPREV for the granting of social security benefits. There was an end to long queues in the benefits of attendance posts, which were reported by the media. Precarious service submitted the insured humiliation in lines that were initiated in the early hours. It started from the analysis of the former service model, which often lived with these long lines, seeking to establish a scenario for that situation before, recorded especially in the nineties, in order to understand the starting point for change. Then analyzed how was this process of change and what were its main agents. Finally, we studied the current care model. There was use of a methodology based on literature, articles, digital sites, newspapers and interviews with professionals who have experienced this process of change, and the use of graphs and tables. We conclude that the process of change improved the care of Social Security.
\end{abstract}

Keywords: DATAPREV. Queues. Benefits stations. Changing. Social Right. 


\section{SUMÁRIO}

INTRODUÇAO; 1 FILAS - DOS ANOS NOVENTA ATÉ 2005; 2 A MUDANÇA - 2005 A 2007; 2 A MUDANÇA 2005 A 2007 -; 2.1 As primeiras ações administrativas e operacionais; 2.20 projeto Madrugada sem Fila; 2.3 A Implantação da Central de Atendimento 135; 2.4 A modernização tecnológica; 2. 0 SISTEMA DE ATENDIMENTO PÓS-MUDANÇAS: 2008 ATÉ OS DIAS ATUAIS; CONCLUSÃO; REFERÊNCIAS.

\section{INTRODUÇÃO}

O crescimento pós-industrial do setor de serviços trouxe algumas mudanças em certos aspectos socioeconômicos do mundo moderno. A informação, por exemplo, passou a ser elemento precioso e fundamental para o sucesso das organizações e objeto de desejo daqueles que procuravam seus serviços. Assim, o movimento natural da demanda de mercado passou a ser das áreas residenciais dos centros urbanos para os locais e postos de atendimento.

Com o passar das décadas do século XX, a demanda mundial no setor de serviços cresceu. Em alguns casos, fez-se necessário organizar o atendimento através de filas. No início, a solução apresentou-se viável, resguardando civilidade e direito. Mas havia uma questão: uma fila ocorre sempre que a procura por um determinado serviço é maior que a capacidade do sistema de fornecer este serviço. As filas então passaram a ser tratadas como um problema, pois geravam espera, ansiedade, irritação e reclamações. As organizações que não tinham a capacidade de eliminá-las viram-se diante de um novo desafio: gerenciá-las. Muitas obtiveram êxito, outras não.

Neste contexto estava inserida também a Previdência Social brasileira, e para ela, infelizmente, viriam as longas filas. A Constituição de 1988 traz no seu artigo $6^{\circ}$ a Previdência Social como um Direito Social do cidadão. Nos anos noventa e até metade da década seguinte, com o aumento dos segurados e o envelhecimento populacional, verificou-se um crescimento significativo na busca por esse direito e pelos benefícios oferecidos pelo sistema protetivo, fato que acarretou o aparecimento de um fenômeno social que ganhou repercussão nacional: as filas.

Nos grandes centros urbanos, passou a ser amplamente registrada e divulgada em todo o país a formação de longas filas nas portas dos postos de benefícios do INSS. Houve relatos de filas que começavam a se formar ainda na madrugada, por pessoas que muitas vezes queriam apenas uma orientação ou informação. Havia pessoas idosas e doentes em busca de dar entrada no pedido de seus benefícios ou de sua revisão, guardadores comercializando lugares na fila, pessoas expostas a céu aberto e atendimento lento. 
ISSN 1981-3694

(DOI): $10.5902 / 1981369419593$

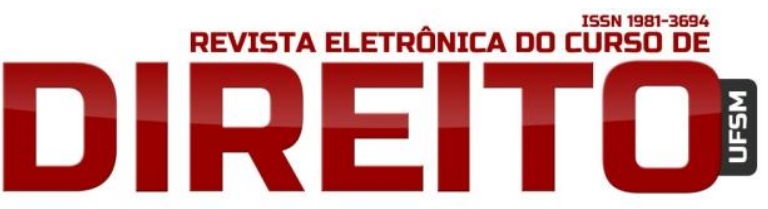

O PROCESSO DE MUDANÇAS ADMINISTRATIVAS E TECNOLÓGICAS QUE PÔS FIM ÀS FILAS NOS POSTOS DE ATENDIMENTO DA PREVIDÊNCIA SOCIAL

SIDNEY SOARES FILHO ROBSON CELSO LEOCÁDIO TOTE

No primeiro tópico do trabalho, verificar-se-á com mais proximidade aquela situação que muitos classificaram como caótica e que tanta preocupação trouxe aos gestores comprometidos com a questão. É extremamente importante essa análise para que se possa em seguida entender como se deu o processo de mudança no atendimento ao segurado, objetivo maior desse trabalho, processo este que ficou conhecido como a "virada" da Previdência Social. Qual era a dimensão do problema das filas? Quais as causas para o problema?

No segundo tópico, a partir deste entendimento da situação do problema, analisar-se-á o processo de mudança, que ocorreu no período de 2005 a 2007. Que caminho levou à "virada"? Quais foram as ações empreendidas visando solucionar o problema das filas? Como essas mudanças foram implantadas? O objetivo principal é apresentar como se deu esse processo de mudança na estrutura de atendimento ao segurado nas unidades da Previdência Social.

No terceiro tópico, uma vez diagnosticada a situação anterior e analisado o processo de mudança pelo qual ela passou, verificar-se-á a situação atual do sistema de atendimento ao segurado. Como está o atendimento hoje? A “virada" realmente se consumou? As mudanças tiveram o efeito esperado?

A metodologia deste trabalho se baseará em estudo bibliográfico e análise de jornais da época. É intenção também realizar um trabalho de campo em algumas agências, buscando informações através de entrevistas com pessoas envolvidas no processo de mudança e no modelo de atendimento atual, e pesquisa em documentos e sistemas de informação.

A opção pelo uso de matérias jornalísticas como fonte de pesquisa deste trabalho ocorre em função da importância que os registros da imprensa têm para o entendimento da realidade do atendimento na época das filas, informações que serão comparadas com dados estatísticos disponíveis sobre o atendimento nos anos seguintes e nos dias de hoje.

\section{FILAS - DOS ANOS NOVENTA ATÉ 2005}

Entre o fim dos anos noventa e o ano de 2004, o segurado que se dirigia ao posto de atendimento do INSS portando seus documentos, a fim de solicitar benefícios ou simplesmente pedir informações, exercendo o seu direito, tinha 70\% (setenta por cento) de chances de voltar 
O PROCESSO DE MUDANÇAS ADMINISTRATIVAS E TECNOLÓGICAS QUE PÔS FIM ÀS FILAS NOS POSTOS DE ATENDIMENTO DA PREVIDÊNCIA SOCIAL

SIDNEY SOARES FILHO ROBSON CELSO LEOCÁDIO TOTE

para casa sem ser atendido, de acordo com Rogério Pacheco Jordão ${ }^{1}$. A causa para esse alto índice: filas.

Na Agência da Previdência Social (APS) de Santo Amaro, na cidade de São Paulo, os anos de 2003 e 2004 foram marcados por momentos críticos no atendimento, com a ocorrência de filas com mais de 1000 pessoas, segundo dados apresentados por Rogério Pacheco Jordão². Tais eventos contavam sempre com a presença dos canais de televisão, que entravam ao vivo, e de programas de rádio. Policiais eram convocados para tentar organizar as filas. Em dias normais de atendimento, as filas seguiam ladeando onze postes ao longo da avenida.

De acordo com Rogério Pacheco Jordão ${ }^{3}$, em São José do Rio Preto (SP) havia tanta fila para acesso a APS Central, que os moradores das casas entraram com ações na Justiça Federal contra o INSS, por obstrução de via pública; no Rio de Janeiro, em Salvador e no Recife as filas também ocupavam quarteirões nas agências mais movimentadas.

Havia, ainda, para piorar a situação, a figura do vendedor de senhas ${ }^{4}$, muito comum nas maiores agências do país. Os vendedores conheciam a rotina de funcionamento das agências e os seus serviços. Chegavam de madrugada e vendiam seus lugares aos segurados que chegavam pela manhã em busca do atendimento devido.

Com relação aos servidores do INSS, a situação revelava mais um problema. Os funcionários eram constantemente insultados e muitas vezes agredidos pelos segurados insatisfeitos, o que tornava a relação ainda mais tensa, gerando um quadro de servidores também descontentes e desmotivados para realizar suas funções. Outros problemas encontrados em muitas agências do país eram a pouca quantidade de servidores experientes e a redução do quadro de pessoal, sem a correspondente reposição através de concursos públicos. Sobre essa questão, Rogério Pacheco Jordão ${ }^{5}$, reproduziu trecho do Relatório de Gestão do INSS 2003-2010:

Em 2003, a situação do quadro de pessoal do INSS era preocupante. Somente no período de 1998 a 2002, houve um decréscimo de 8,40\% no número de servidores. Nesse mesmo ano, completava-se mais uma década sem a realização de concurso

\footnotetext{
1 JORDÃO, Rogério Pacheco. A virada da Previdência Social: como acabaram as filas nas portas das agências. 1. ed. Brasília: DATAPREV, 2013. p.14.

2 JORDÃO, Rogério Pacheco. A virada da Previdência Social: como acabaram as filas nas portas das agências. 1. ed. Brasília: DATAPREV, 2013. p.11.

3 JORDÃO, Rogério Pacheco. A virada da Previdência Social: como acabaram as filas nas portas das agências. 1. ed. Brasília: DATAPREV, 2013. p.14.

${ }^{4}$ Informativo Quinzenal das Diretorias Estaduais da ANASPS - Ano V, Edição n. ${ }^{\circ} 143$ - Brasília 30 de Setembro de 2006. Disponível em: <http://www.anasps.org.br/imprimir_materia.php?id=1307.>. Acesso em: 05 agosto 2015.

5 JORDÂO, Rogério Pacheco. A virada da Previdência Social: como acabaram as filas nas portas das agências. 1. ed. Brasília: DATAPREV, 2013. p.16.
} 
público específico para o INSS (quadro revertido no mês de janeiro de 2003), o que aumentava, cada vez mais, a dependência da utilização de força de trabalho terceirizada (a terceirização ganhou impulso no final dos anos 90), inclusive em áreas finalísticas da instituição (...) tornou-se premente a recomposição do seu quadro de pessoal.

Nos anos 90, a terceirização foi o mecanismo adotado pela Administração Pública para dotar o INSS de mão de obra capaz de fazê-lo cumprir seus objetivos institucionais, já que havia orientação governamental contrária à realização de concursos públicos ${ }^{6}$. Mas, o que foi pensado inicialmente como uma solução passou a ser mais um problema para a autarquia. Rogério Pacheco Jordão ${ }^{7}$ reproduz depoimento de um servidor que viria a ser presidente do INSS na década seguinte, o auditor-fiscal Valdir Moysés Simão:

Houve uma decisão da área técnica de que a pessoa que prestava o atendimento
poderia tomar decisão sobre o benefício. Até então, quem decidia era um servidor
concursado. Em 2002 se permitiu que o terceirizado pudesse decidir se o segurado
tinha o direito ao benefício. Lembrando que àquela época o segurado tinha que
comprovar que contribuiu, que trabalhou para ter direito ao benefício (o
reconhecimento automático de direitos seria realidade, em maior escala, apenas
anos mais tarde). Mas os órgãos de controle não permitiam que isso acontecesse,
era uma atividade-fim e teria que ser exercida por um servidor. Por uma
provocação do Tribunal de Contas da União, no início de 2003, o governo
reconheceu isso e foi autorizada a abertura de concurso público que não acontecia
há muito tempo.

Em 2003 a terceirização começou a perder força e após 10 anos sem concursos públicos foram abertas 4.400 (quatro mil e quatrocentas) vagas para os cargos de analistas e técnicos previdenciários, de acordo com Rogério Pacheco Jordão ${ }^{8}$. 0 processo de transição entre a saída dos terceirizados e a chegada e preparação dos novos contratados sem experiência com o público foi mais um problema que repercutiu diretamente no atendimento aos segurados.

Havia ainda uma cultura antiga de conformismo e acomodação dentro do Instituto, inclusive em nível gerencial, que precisava ser combatida; cultura esta que na questão do tratamento das filas não era diferente. João Maria Lopes ${ }^{9}$, servidor e hoje Superintendente da Regional Nordeste do INSS, registrou, em seu livro intitulado "Fila, solução do passado, desafio

\footnotetext{
6 JORDÃO, Rogério Pacheco. A virada da Previdência Social: como acabaram as filas nas portas das agências. 1. ed. Brasília: DATAPREV, 2013. p.31.

7 JORDÃO, Rogério Pacheco. A virada da Previdência Social: como acabaram as filas nas portas das agências. 1. ed. Brasília: DATAPREV, 2013. p.17.

8 JORDÃO, Rogério Pacheco. A virada da Previdência Social: como acabaram as filas nas portas das agências. 1. ed. Brasília: DATAPREV, 2013. p.16.

9 LOPES, João Maria. Fila: solução no passado, desafio no presente, diferencial no futuro. 1. ed. Natal: JLCH2, 2007. p. 18.
} 
do presente, diferencial no futuro", a manifestação desse sentimento, a qual teve a oportunidade de presenciar:

No ano de 2002, fiz uma palestra para os Gerentes Executivos do INSS da Região IV (...). Na época eu dizia que o combate da fila era uma questão de gestão, para isso era preciso atitudes dos gerentes executivos (...). Apresentei várias matérias veiculadas nos jornais do país denunciando essas enormes filas.

Por incrível que pareça, teve quem defendesse a fila, alegando que ela só existe onde há alguma coisa boa (...). Portanto, nosso serviço era bom e importante, por isso se justificavam as filas. Diziam mais: - Espero que as filas nunca acabem!

Em 2003 houve uma importante tentativa coordenada de analisar criteriosamente a engrenagem de atendimento de uma agência da Previdência Social e propor soluções para a melhoria deste serviço. Esse esforço foi denominado PGA - Projeto de Gestão do Atendimento e abrangeu cinco agências de atendimento da cidade de São Paulo, resultando, inclusive, na melhoria dos indicadores de desempenho das unidades envolvidas e na identificação de mudanças de gestão que poderiam ser levadas a outras agências no país.

Experiência conhecida como Projeto de Gestão do Atendimento (PGA) que experimentou, a partir de 2003, novas formas de trabalhar no interior das agências, com foco na participação dos servidores e no trabalho por processos. Muitas ideias trabalhadas pelo PGA neste período - o programa piloto envolveu cinco agências paulistanas, entre elas a de Santo Amaro, e foi uma tentativa de aplicar nas agências novos princípios de gestão - foram incorporadas à maneira como o trabalho é organizado no interior das APS até os tempos atuais. Noções como metas, medição de resultados e foco no cidadão, ganharam corpo naquele momento para depois, e de diferentes formas, espalharem-se para toda a instituição ${ }^{10}$.

O grupo de consultores do PGA, formado por servidores do INSS, analisou todo o processo de funcionamento da agência de Santo Amaro e identificou um grupo de problemas que fatalmente refletia na baixa qualidade do atendimento dado ao segurado e no alto tempo de concessão dos benefícios solicitados. Rogério Pacheco Jordão ${ }^{11}$ reproduz esses problemas observados e que constaram de um relatório elaborado em setembro de 2004 pelo PGA:

Baixa "resolutividade" de benefícios com baixo nível de complexidade (Pagamentos atrasados de benefícios. (...) A fila às 7 da manhã começa na porta da APS e estende-se por 250 metros, "misturando idosos, inválidos, doentes, procuradores, representantes de empresa (...) Arquivos desorganizados.

\footnotetext{
10 JORDÃO, Rogério Pacheco. A virada da Previdência Social: como acabaram as filas nas portas das agências. 1. ed. Brasília: DATAPREV, 2013. p.22.

11 JORDÃO, Rogério Pacheco. A virada da Previdência Social: como acabaram as filas nas portas das agências. 1. ed. Brasília: DATAPREV, 2013. p.23.
} 
ISSN 1981-3694

(DOI): $10.5902 / 1981369419593$

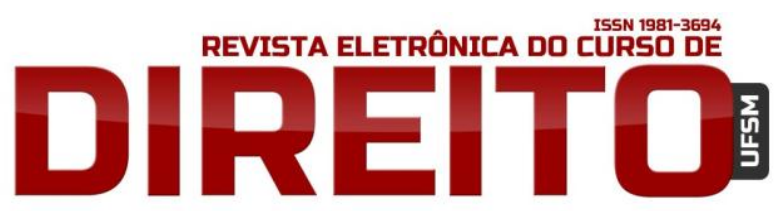

O PROCESSO DE MUDANCAS ADMINISTRATIVAS E TECNOLÓGICAS QUE PÔS FIM ÀS FILAS NOS POSTOS DE ATENDIMENTO DA PREVIDÊNCIA SOCIAL

SIDNEY SOARES FILHO ROBSON CELSO LEOCÁDIO TOTE

Distanciamento entre chefe da APS e equipe. Não existe critério de alocação de servidores. Alta rotatividade dos servidores (...). Não há gestão participativa; sugestão de servidor não é levada em conta.

Portanto, esse era o quadro no qual estava inserida a Previdência Social. Um cenário confuso, extremamente desfavorável para a instituição, constantemente criticada pela imprensa e pela opinião pública, desgastada pelas filas, com servidores desmotivados, longe de cumprir seu papel social previsto em lei, enfim, desacreditada. Mudanças eram necessárias.

\section{A MUDANÇA - 2005 A 2007}

Em 2005 Nélson Machado assume o Ministério da Previdência Social com duas tarefas bem claras, estabelecidas pelo próprio Presidente da República: acabar com as filas e combater as fraldes $^{12}$. Em sua primeira reunião com o Presidente Lula, duas diretrizes foram estabelecidas: valorização do funcionário público e profissionalização da gestão. Foi consenso entre ambos que sem essas duas ações não obteriam sucesso.

Nas próximas seções serão apresentadas as medidas tomadas pela nova gestão, que contemplaram ações estratégicas e operacionais dentro da organização: o vitorioso projeto Madrugada Sem Filas, que levou os servidores para as ruas nas madrugadas com o objetivo de entender e acabar com o problema; a implantação da Central 135 e do serviço de agendamento, que foi o principal responsável pelo fim das filas externas.

\subsection{As primeiras ações administrativas e operacionais}

Uma das primeiras medidas do novo ministro foi o deslocamento das áreas de arrecadação e fiscalização do INSS para a Receita Federal. Essa providência proporcionou ao Ministério concentrar-se mais na questão das filas, já que aquelas pastas exigiam muito da capacidade laborativa do órgão. Livre da arrecadação e da fiscalização, o foco passou a ser maior sobre a área de benefícios.

12 JORDÃO, Rogério Pacheco. A virada da Previdência Social: como acabaram as filas nas portas das agências. 1. ed. Brasília: DATAPREV, 2013. p.31. 
ISSN 1981-3694

(DOI): $10.5902 / 1981369419593$

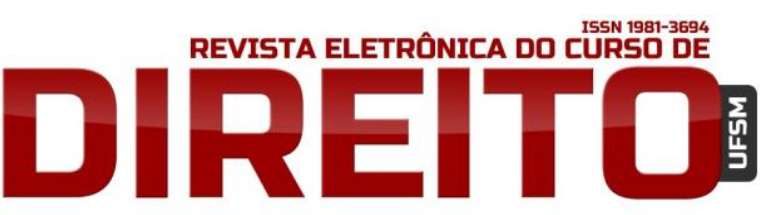

O PROCESSO DE MUDANÇAS ADMINISTRATIVAS E TECNOLÓGICAS QUE PÔS FIM ÀS FILAS NOS POSTOS DE ATENDIMENTO DA PREVIDÊNCIA SOCIAL

SIDNEY SOARES FILHO ROBSON CELSO LEOCÁDIO TOTE

Outras importantes deliberações administrativas foram tomadas. Foi extinta a Diretoria Colegiada que estava subordinada à Presidência. Foram extintas nove Superintendências Regionais que estavam sem finalidade funcional. Foi criada a Diretoria de Atendimento, que teria futuramente atuação destacada no diagnóstico do problema das filas e no monitoramento dos resultados alcançados. Foram criadas cinco Gerências Regionais e função gratificada para chefia de APS.

Havia toda uma cultura de trabalho vigente há anos que deveria ser eliminada em benefício de uma nova ordem dentro do Instituto. Foi então que se buscou um conjunto de ações integradas que envolvesse várias áreas por certo período de tempo. Essa nova ordem ficou conhecida como a "profissionalização da Gestão da Previdência Social”.

Porém, mesmo antes de essas ações articuladas e integradas saírem do papel, providências práticas operacionais imediatas foram tomadas no ano de 2005: a expansão do horário de atendimento das agências, já que muitas delas vinham atendendo apenas meio expediente; a obrigação de atender todos os segurados presentes na agência e o fortalecimento do atendimento agendado.

\subsection{0 projeto Madrugada sem Fila}

Em janeiro de 2006, o Presidente Lula, em visita a cidade do Recife, prometeu acabar com as filas em três meses. João Maria Lopes ${ }^{13}$ relembra aquele momento político: “Tudo começou com o pronunciamento do Presidente da República, que garantiu à nação brasileira, por meio da imprensa, que em abril de 2006 não haveria mais filas nas Agências da Previdência Social.".

Em maio daquele ano a imprensa tratou de verificar se a promessa do Presidente havia sido cumprida pelo INSS, mas, em visitas a algumas agências, os órgãos de comunicação encontraram longas filas e divulgaram que o problema continuava, e que a promessa não se cumprira. João Maria Lopes ${ }^{14}$ coletou e registrou essas manchetes:

Jornal da Tarde - Estado de São Paulo - 20/05/2006. "Promessas do INSS não saem do papel."

\footnotetext{
${ }^{13}$ LOPES, João Maria. Fila: solução no passado, desafio no presente, diferencial no futuro. 1. ed. Natal: JLCH2, 2007. p. 35.

${ }_{14}$ LOPES, João Maria. Fila: solução no passado, desafio no presente, diferencial no futuro. 1. ed. Natal: JLCH2, 2007. p. 36.
} 
Jornal Nacional - Globo - 24/05/2006. "Filas em postos do INSS não acabam". - No início do ano, os brasileiros ouviram, por duas vezes, uma promessa do governo federal: as filas nas agências do INSS iriam acabar.

JB on-line - Rio de Janeiro - 24/05/2006. "Pedreiro morre na fila do INSS" - vítima queria pedir aposentadoria...Após ficar 12 horas na fila, parte desse tempo sob o sol forte, Severino morreu...

FUNAPE - Fundação de Aposentados e Pensionistas do Estado de Pernambuco 24/05/2006. Atendimento empaca na fila. Presidente Lula prometeu acabar, em três meses, o tempo de espera nas agências do INSS, mas segurados têm dificuldades nos postos.

As notícias atingiram não só o Presidente Lula e o Ministro da pasta Nelson Machado, mas todo o corpo gerencial e funcional do INSS. Naquele período, em Recife, um grupo de servidores apresentou à Gerente Regional do INSS da Região IV um projeto intitulado Madrugada sem Fila, dentro do Programa de Gestão do Atendimento (PGA) iniciado em 2003. A gestora decidiu pôr a proposta em prática de imediato.

Basicamente o projeto tinha os seguintes pontos: objetivo - combater as filas nas Agências da Previdência Social que varavam a madrugada em Recife e Olinda; missão - não permitir que qualquer pessoa passe a noite na fila ou tenha que comprar senha para conseguir o atendimento nas Agências da Previdência Social ${ }^{15}$.

Esperava-se em 30 dias acabar com as filas nas madrugadas nas duas cidades. Para isso, o projeto pôs em prática ações importantes. Entre elas, abrir as agências às 5 (cinco) horas utilizando servidores voluntários, conforme descrição contida no bojo do projeto:

A lógica da antecipação do atendimento é começar antes da hora da venda de lugares na fila, com isso, inibir a ação dos vendedores. Não tendo quem compre (senha), os atravessadores somem, e a fila deixa de existir, já que são eles quem as mantém ${ }^{16}$.

O projeto, em sua descrição, previa também que, paralelamente ao atendimento, haveria palestras de conscientização, informando ao segurado que, na próxima vez, poderiam agendar uma perícia ou requerer um benefício através da nova central 135, que entraria no ar em 15 dias, ou pela internet.

\footnotetext{
${ }^{15}$ LOPES, João Maria. Fila: solução no passado, desafio no presente, diferencial no futuro. 1. ed. Natal: JLCH2, 2007. p. 39.

${ }^{16}$ LOPES, João Maria. Fila: solução no passado, desafio no presente, diferencial no futuro. 1. ed. Natal: JLCH2, 2007. p. 39.
} 
ISSN 1981-3694

(DOI): $10.5902 / 1981369419593$

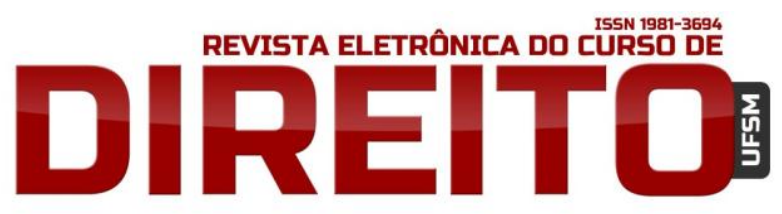

O PROCESSO DE MUDANCAS ADMINISTRATIVAS E TECNOLÓGICAS QUE PÔS FIM ÀS FILAS NOS POSTOS DE ATENDIMENTO DA PREVIDÊNCIA SOCIAL

SIDNEY SOARES FILHO ROBSON CELSO LEOCÁDIO TOTE

O projeto Madrugada sem Fila foi considerado coberto de êxito. Já em sua edição de 20 de junho de 2006, o PrevNotícias, boletim de notícias do MPS, publicou memorável nota. João Maria Lopes ${ }^{17}$, servidor do INSS e um dos idealizadores e executores do projeto, reproduziu:

INSS acaba com as filas da madrugada

Foi preciso mudar a rotina dos servidores do INSS e conscientizar os segurados

De Recife (PE) - As filas de segurados nas Agências de Previdência Social (APS) não existem mais. Os atravessadores não são vistos nas proximidades das agências e a venda de lugares nas filas acabou. O que parecia impossível agora é uma realidade.

O projeto Madruga Sem Fila, como visto, empenhou-se bastante em divulgar aos segurados nas filas a nova forma de atendimento, baseada no agendamento por telefone, o que confirma a importância do novo sistema para a consolidação do processo de eliminação das filas. Sobre ele foram depositadas a expectativa e a esperança de todos.

\subsection{A Implantação da Central de Atendimento 135}

Durante os anos 90, o INSS manteve em operação duas unidades de atendimento telefônico ao segurado, as Centrais 191, como ficaram conhecidas, uma em Brasília e outra em Salvador, fazendo uso do sistema 0800. Somente em junho de 2006, foi inaugurado o primeiro “call center" 135, em Recife, após processo licitatório para contratação às pressas de uma empresa terceirizada, para honrar promessa do Presidente Lula.

Com o êxito do projeto Madrugada sem Filas, que seria posteriormente reproduzido em outras capitais nordestinas, o terreno pernambucano estava devidamente preparado para a iminente implantação da nova central de teleatendimento, a 135, que viria como elemento consolidador do esforço realizado em campo, objetivando o fim das filas no estado.

O principal diferencial da Central 135 para a antiga Central 191 foi a inclusão do serviço de agendamento massivo do atendimento. O segurado passaria a fazer, com o auxílio do operador, o agendamento do seu próprio atendimento presencial na Agência da Previdência Social (APS), por telefone. Assim, não necessitaria mais se deslocar de madrugada, mas sim posteriormente, em data e hora marcadas, dentro do horário de funcionamento normal da APS. Além desse, outros serviços foram acrescentados à nova central.

\footnotetext{
17 LOPES, João Maria. Fila: solução no passado, desafio no presente, diferencial no futuro. 1. ed. Natal: JLCH2, 2007. p. 42.
} 
ISSN 1981-3694

(DOI): $10.5902 / 1981369419593$

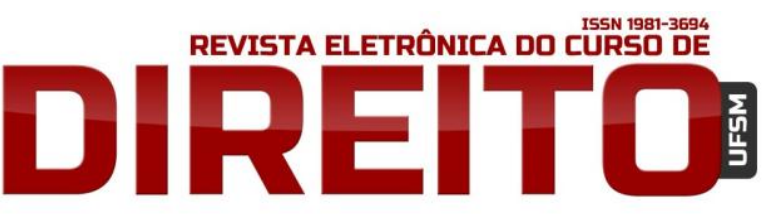

O PROCESSO DE MUDANCAS ADMINISTRATIVAS E TECNOLÓGICAS QUE PÔS FIM ÀS FILAS NOS POSTOS DE ATENDIMENTO DA PREVIDÊNCIA SOCIAL

SIDNEY SOARES FILHO ROBSON CELSO LEOCÁDIO TOTE

0 projeto Madrugada sem Fila e a inauguração da Central 135 foram um marco. Em dois meses as filas em Recife e Olinda foram zeradas ${ }^{18}$. Em agosto de 2006, a notícia do sucesso da ação conjunta foi inclusive veiculada no mesmo PREVNotícias. 0 agendamento eletrônico deu, assim, a sua primeira demonstração de que, de fato, seria uma arma poderosa contra as indesejáveis filas.

Nas Centrais 135 o serviço de atendimento é terceirizado. Cabem ao INSS o monitoramento do trabalho de atendimento da contratada e a verificação do cumprimento do contrato. A responsabilidade pela gestão dos recursos humanos da central é da própria empresa contratada. Como as leis, normas e regras previdenciárias mudam com frequência, outra atribuição do INSS nas Centrais 135 é repassar ao setor de atendimento da empresa terceirizada as novas orientações a serem prestadas aos segurados. O gráfico abaixo mostra o perfil do atendimento nesta APS em análise, segundo Rogério Pacheco Jordão ${ }^{19}$.

\section{Grafico 1 - Perfil do atendimento nesta APS em análise}

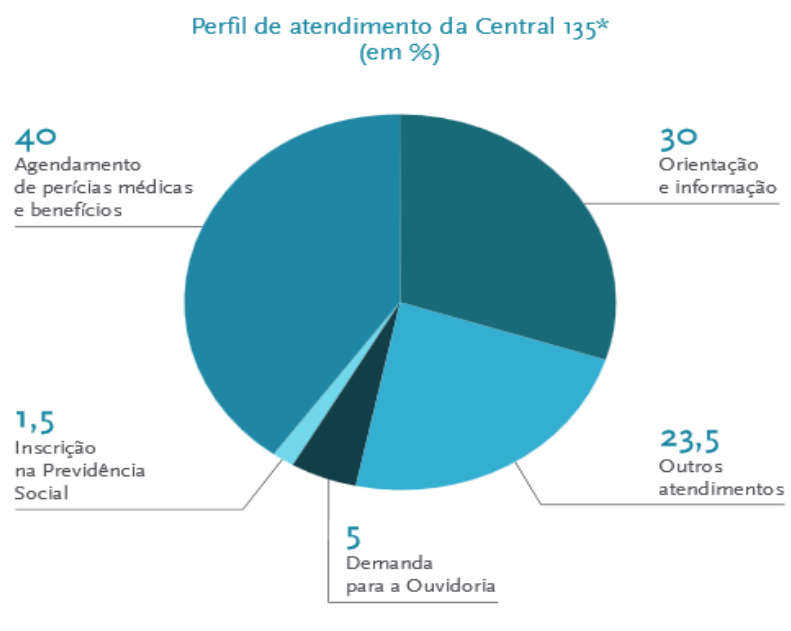

* Ano de 2009 . Apenas atendimento humano, consultas eletrônicas não incluídas

É fácil observar que trinta por cento das pessoas que ligaram para a central no ano de 2009 estavam procurando apenas informação ou orientação, e essas mesmas pessoas iriam às agências do INSS com esse mesmo propósito, ocasionando filas, se não houvesse o atendimento

18 JORDÃO, Rogério Pacheco. A virada da Previdência Social: como acabaram as filas nas portas das agências. 1. ed. Brasília: DATAPREV, 2013. p.43.

19 JORDÃO, Rogério Pacheco. A virada da Previdência Social: como acabaram as filas nas portas das agências. 1. ed. Brasília: DATAPREV, 2013. p.46. 
pelo 135. Observa-se também que quarenta por cento das ligações são para agendamentos de visitas às agências, número representativo após 4 anos de implantação da Central 135, compondo um montante de segurados que vai comparecer a sua agência no dia e hora marcados, sem a necessidade de chegar de madrugada e enfrentar filas.

Inicialmente, o acompanhamento dos efeitos das medidas foi realizado pelos próprios gerentes das APS, através da contagem manual do número de pessoas na porta das agências no momento de sua abertura e do repasse desses dados à Diretoria de Atendimento do INSS, para consolidação. Observa-se que, gradativamente, em dois anos, as filas foram sendo reduzidas nas agências, como consequência deste conjunto integrado de ações do MPS, posto em prática a partir do ano de 2005. De dezembro de 2005 a dezembro de 2007, a média nacional de pessoas nas filas das APS caiu de oitenta e duas para quatorze $e^{20}$.

\subsection{A modernização tecnológica}

O modelo de mudança pretendido na Previdência Social, principalmente em uma instituição do porte do INSS, não seria possível sem o apoio da tecnologia. Se por um lado as ações administrativas, as medidas organizacionais e operacionais foram importantes, a efetivação dessa mudança exigia a adequação tecnológica necessária. Coube à empresa pública DATAPREV - Empresa de Tecnologia da Informação da Previdência Social, membro do MPS, oferecer consultoria e soluções tecnológicas para as necessidades do seu principal cliente e parceiro, o INSS.

Em meados de 2005, ficava claro que, para levar a cabo as transformações profundas no modo de atendimento do INSS, seriam necessários, cada vez mais, investimentos na estratégica área de tecnologia da informação. Realizar milhões de agendamentos via teleatendimento, e depurar estes dados, significa, na prática, ficar-se cada vez mais dependente de sistemas ou redes, ou seja: milhões de informações precisam trafegar de modo rápido e seguro, atendendo, no final da linha, a demandas por mais e novos serviços ${ }^{21}$.

O SGA - Sistema de Gerenciamento de Atendimento, incorporado pela DATAPREV, passou a controlar dentro das APS a distribuição eletrônica de senhas e todo o atendimento presencial. Em 2005, a estatal desenvolveu o SAE - Sistema de Agendamento Eletrônico, cuja finalidade era

20 JORDÃO, Rogério Pacheco. A virada da Previdência Social: como acabaram as filas nas portas das agências. 1. ed. Brasília: DATAPREV, 2013. p.53.

21 JORDÃO, Rogério Pacheco. A virada da Previdência Social: como acabaram as filas nas portas das agências. 1. ed. Brasília: DATAPREV, 2013. p.51. 
prover a comunicação final entre a APS e o teleatendimento da Central 135, fazendo por meio da Internet a programação do agendamento, a partir da informação da quantidade de vagas disponíveis em cada APS para cada tipo de serviço.

Com base nisso o call center indicava que o cidadão seria atendido em determinada agência. E cada novo serviço disponibilizado na internet era incorporado ao SAE. Era necessário adaptar o sistema para poder aumentar o volume de serviço na internet, ver a infraestrutura para viabilizar isso, ajustar a rede para se integrar aos call centers, aumentar o link de internet, revisar o modelo de navegação do site ${ }^{22}$.

Para suportar realmente toda essa demanda por tráfego de rede foi necessário um redimensionamento da capacidade de transmissão dos links (meio físico para o tráfego de dados) envolvendo a troca de dados entre as agências, gerências e centrais de atendimento espalhadas pelo país. De acordo com o relatório 2006_M10_285817_V00_região_I_CE_23_10_2006-123 da DATAPREV, unidade do Estado do Ceará, a capacidade de transmissão em Kbps (Kilobits por segundo) das agências no estado era em sua maioria de $64 \mathrm{Kbps}$, configuração insuficiente para o novo modelo de atendimento, que fatalmente acarretaria em lentidão nos sistemas implantados. Assim, a grande maioria dos links passou para 256Kbps. Algumas agências maiores no estado chegaram a $512 \mathrm{Kbps}$, e $1 \mathrm{Mbps}$ em duas agências na capital. 0 mesmo ocorreu em praticamente todos os estados do país.

Em 2005 a situação do parque computacional no Instituto era de defasagem em relação à tecnologia disponível no mercado. Uma renovação dos equipamentos era necessária para que o INSS pudesse ter a infraestrutura adequada para sustentar todo o arsenal de programas de computadores necessário para o serviço de agendamento.

Do lado do INSS, fez-se um processo pesadíssimo entre 2005 e 2008 de renovação do parque de equipamentos, como impressoras e estações de trabalho. As 50 mil máquinas do INSS foram substituídas nessa janela de tempo. Os equipamentos eram defasados em relação aos sistemas que estavam entrando, sendo que até a melhoria dos sistemas antigos já demandava uma estrutura melhor ${ }^{24}$.

Portanto, com a melhoria e o desenvolvimento dos novos programas computacionais, o aumento da capacidade da rede de transmissão de dados e a atualização do parque

\footnotetext{
22 JORDÃO, Rogério Pacheco. A virada da Previdência Social: como acabaram as filas nas portas das agências. 1. ed. Brasília: DATAPREV, 2013. p.51.

${ }_{23}^{23}$ MPS. Manual de Identidade Visual da Previdência Social. 8 ed. Brasília: MPS, 2008. p. 38

24 JORDÃO, Rogério Pacheco. A virada da Previdência Social: como acabaram as filas nas portas das agências. 1. ed. Brasília: DATAPREV, 2013. p.51.
} 

mudança no atendimento ao segurado.

\title{
30 SISTEMA DE ATENDIMENTO PÓS-MUDANÇAS: DE 2008 ATÉ OS DIAS
}

\section{ATUAIS}

O problema das filas nas agências representou durante vários anos uma fonte de pressão constante sobre os gestores da Previdência Social no Brasil. Era inapropriado se pensar em melhorias na gestão e no processo de trabalho, com o INSS sendo permanentemente massacrado pelos meios de comunicação e pela opinião pública, em função do problema das filas. Com o fim delas, os gestores puderam se dedicar exclusivamente ao estudo da gestão previdenciária, identificar novas oportunidades de melhoria na administração do órgão e consolidar o processo de eliminação das filas, através do aprimoramento do atendimento proporcionado pelas agências, centrais e demais áreas envolvidas. Assim, foram deliberadas novas medidas que marcariam positivamente o futuro do INSS, como o Reconhecimento Automático de Direitos e a implantação das Salas de Monitoramento. Relata Rogério Pacheco Jordão ${ }^{25}$ :

\begin{abstract}
Sob esta direção geral foram tomadas medidas que marcariam os anos pós-fim das filas nas portas das agências, como o reconhecimento automático de direitos (em 2009, que permitiu a massificação do atendimento em 30 minutos), o Plano de Expansão (que visa dotar todas as cidades acima de 20 mil habitantes com uma APS), a Sala de Monitoramento (que permite um acompanhamento em tempo real dos serviços das agências em todo o País), entre outras.
\end{abstract}

Àquela altura as notícias relacionadas à Previdência Social haviam mudado consideravelmente. Já no ano de 2009 os principais jornais do país traziam matérias destacadas abordando a novidade no atendimento ao segurado: alguns benefícios estavam sendo concedidos em 30 minutos nas APS, como aposentadoria e salário-maternidade.

A aposentadoria em 30 minutos só foi possível com o advento da Lei Complementar 128, de 19 de dezembro de 2008, que redundou no aumento da base de dados certificada do Cadastro Nacional de Informações Sociais (CNIS), formado por dados coletados da Caixa Econômica Federal, do Banco do Brasil e do Ministério do Trabalho e Emprego, por meio do Cadastro Geral

25 JORDÃO, Rogério Pacheco. A virada da Previdência Social: como acabaram as filas nas portas das agências. 1. ed. Brasília: DATAPREV, 2013. p.64. 
ISSN 1981-3694

(DOI): $10.5902 / 1981369419593$

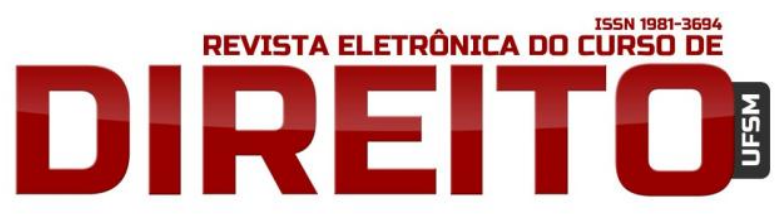

O PROCESSO DE MUDANCCAS ADMINISTRATIVAS E TECNOLÓGICAS QUE PÔS FIM ÀS FILAS NOS POSTOS DE ATENDIMENTO DA PREVIDÊNCIA SOCIAL

SIDNEY SOARES FILHO RoBson CELSO LEOCÁDIO TOTE

de Empregados e Desempregados (CAGED). Assim sendo, o artigo 29-A da citada lei autorizou o INSS a considerar sem restrições as informações de vínculos empregatícios e remunerações dos trabalhadores constantes do CNIS, o que propiciou o reconhecimento automático do direito do segurado no momento de conceder o benefício. Rogério Pacheco Jordão ${ }^{26}$ descreve assim essa nova abordagem, que passou a ser conhecida como Inversão do Ônus da Prova:

Isso passou a significar, na prática, que o cidadão que possuísse todas as informações no cadastro não precisava mais "provar" que contribuiu para ter acesso ao direito. Em outras palavras: invertia-se o ônus da prova, do cidadão para - Estado, que assumia serem verdadeiras, e passíveis de serem tomadas judicialmente, as informações em seus próprios cadastros.

A Inversão do Ônus da Prova foi um marco na Previdência Social brasileira e foi mais um fator responsável pelo fim das filas nos postos de atendimento do INSS. A alteração se deu no tratamento dado às informações constantes nos bancos de dados. Anteriormente, se os dados sobre vínculos empregatícios do segurado estivessem presumidamente incompletos, o cidadão era obrigado a comprovar toda a sua vida laboral através de documentos. Com o reconhecimento automático de direito, as informações que constassem no banco de dados da Previdência Social teriam a automática garantia da veracidade, cabendo ao segurado comprovar por papel apenas o que não estava nos cadastros eletrônicos.

Outro pilar importante para o serviço prestado hoje pelo INSS ao cidadão é o monitoramento do atendimento na APS. Isso ocorre em um espaço físico da agência, conhecido como Sala de Monitoramento. Lançada em 2010, a Sala de Monitoramento estava instalada em mais de 1400 agências pelo país já em $2013^{27}$, proporcionando hoje um acompanhamento em tempo real do atendimento em todas as APS do país. A partir dos dados coletados automaticamente a cada 15 minutos pelas Salas de Monitoramento, os chefes e os servidores das agências têm indicadores valiosos que revelam como está sendo o atendimento, tais como a quantidade de pessoas atendidas, o tempo de espera para ser atendido, o tempo médio em atendimento, o tempo médio de concessão de um determinado benefício ou os procedimentos adotados pelo servidor. Rogério Pacheco Jordão comenta a importância das Salas de Monitoramento.

26 JORDÃO, Rogério Pacheco. A virada da Previdência Social: como acabaram as filas nas portas das agências. 1. ed. Brasília: DATAPREV, 2013. p.74.

27 JORDÃO, Rogério Pacheco. A virada da Previdência Social: como acabaram as filas nas portas das agências. 1. ed. Brasília: DATAPREV, 2013. p.83. 
Do gerente da APS até o ministro - passando por gerentes-executivos, superintendentes, diretores e presidente do INSS (em suma, todos os responsáveis diretos por manter bons índices de atendimento, o que inclui a Dataprev) - podese saber, na hora, onde há problemas, facilitando a busca por soluções. As informações são também visualizadas pela Casa Civil e pela própria Presidência da República. (JORDÃO, 2013, p.84).

(...)

Ministro da Previdência Social a partir de janeiro de 2011, o senador potiguar Garibaldi Alves Filho classifica o processo de gestão da Previdência, e em especial a Sala de Monitoramento, como "revolucionário" (no início de 2012 a Presidência da República encaminharia estudos para replicar a experiência do monitoramento em diversos âmbitos do Governo Federal) ${ }^{28}$.

Em 2008, o Presidente do INSS, Marco Antônio de Oliveira, considerando a necessidade de adequação da infraestrutura das Agências da Previdência Social ao novo modelo de atendimento ao segurado, assinou a Resolução INSS/PRESS $n^{\circ}$ 62, de 09 de dezembro de 2008 - DOU de 11/12/2008, que aprovou o Manual de Procedimentos para Adequação da Infraestrutura das Agências da Previdência Social ${ }^{29}$.

O Manual de Procedimentos buscou adotar e padronizar uma estrutura física considerada ideal para o novo perfil das APS. O documento aborda a setorização das agências, o uso dos espaços físicos, o layout, o fluxo de circulação, a identidade visual, os mobiliários e as atividades de cada área. As preocupações agora eram o tratamento e o conforto do cliente dentro da agência, uma sinalização visual clara, o bom uso do modelo de atendimento com senhas eletrônicas, apoiado pelo SGA, a divulgação do serviço de agendamento da Central 135 e da Internet. O Manual de Procedimentos determinou também que a padronização e a identidade visual das agências obedeceriam ao Manual de Identidade Visual da Previdência Social, em sua $8^{a}$ e última edição, publicada em Janeiro de 2008, que trouxe o visual externo e interno que as Agências da Previdência Social mantêm até hoje.

Para verificar presencialmente como está sendo realizado e monitorado hoje o atendimento ao segurado, em dezembro de 2014, o autor dessa pesquisa esteve em duas APS, uma em Fortaleza e outra no interior do estado do Ceará, no município de Sobral. 0 objetivo foi também observar se ainda estava havendo a formação de filas externas. Alguns servidores foram entrevistados e foi feito registro fotográfico externo e interno nas agências.

Este autor chegou no dia 9 de dezembro, às 10 horas, à APS de Sobral. Não foram verificadas filas externas na agência neste horário, apenas um pequeno movimento normal de

28 JORDÃO, Rogério Pacheco. A virada da Previdência Social: como acabaram as filas nas portas das agências. 1. ed. Brasília: DATAPREV, 2013. p.86.

${ }^{29}$ MPS. Manual de Identidade Visual da Previdência Social. 8 ed. Brasília: MPS, 2000. 
ISSN 1981-3694

(DOI): $10.5902 / 1981369419593$

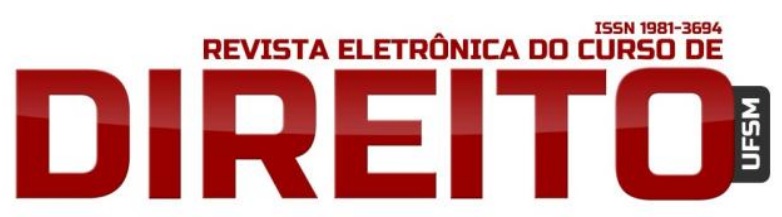

O PROCESSO DE MUDANCAS ADMINISTRATIVAS E TECNOLÓGICAS QUE PÔS FIM ÀS FILAS NOS POSTOS DE ATENDIMENTO DA PREVIDÊNCIA SOCIAL

SIDNEY SOARES FILHO ROBSON CELSO LEOCÁDIO TOTE

pessoas na entrada do edifício. Os servidores Fernando Tadeu Ribeiro e Osires Henriques Costa foram designados para prestar informações, além do próprio chefe da agência naquele dia, Leonardo Benício. Abaixo segue foto da entrada principal da APS de Sobral (CE) no período da manhã, às 10 horas.

Nesta APS, antes do advento da Central 135, havia filas externas que se formavam antes da abertura da agência, entre três e meia e quatro horas da manhã, diariamente, para esperar o atendimento às sete e meia, quando a agência abria suas portas. A figura do guardador de filas era comum nas filas externas - indivíduos que visavam aos ganhos financeiros com a negociação do lugar na fila na chegada dos segurados pela manhã. Havia ainda a figura do despachante, ou atravessadores. Estes, à época das filas, conhecendo da sistemática dos benefícios e dos trâmites dentro da agência, ofereciam seus serviços aos segurados, prometendo poupar-lhes tempo e esforço físico.

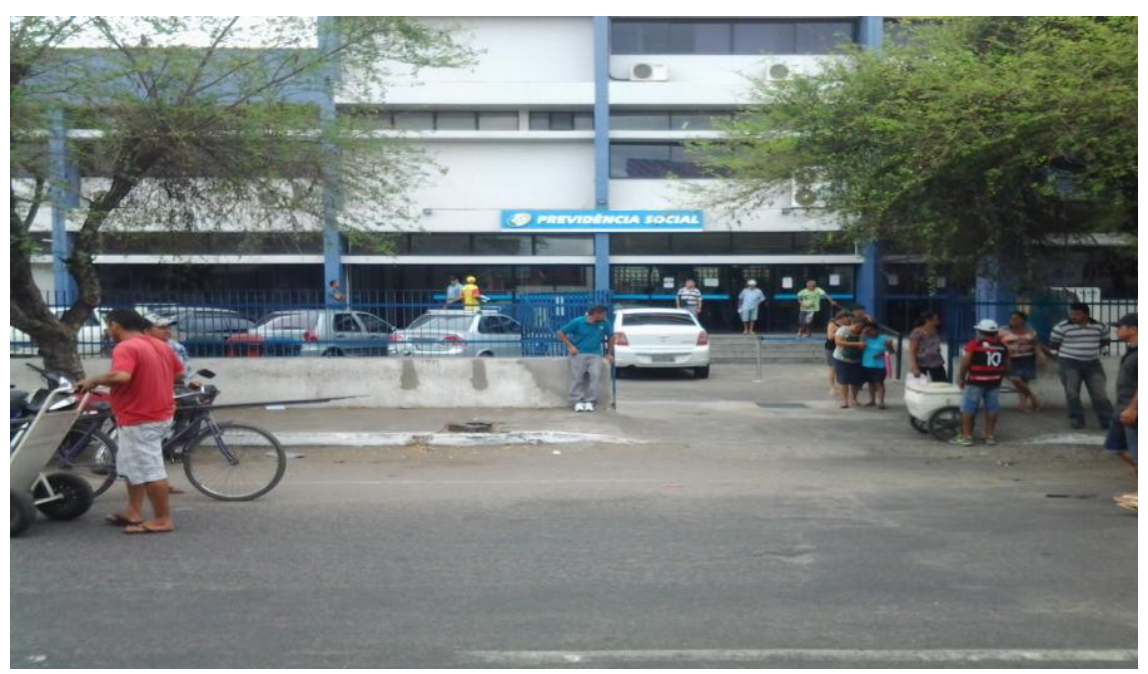

Foto 1: Evidência produzida pelo próprio autor de que não havia fila chegou no dia 9 de dezembro de 2014, às 10 horas, na APS de Solbral (Ce)

Nesta agência, através do uso do sistema de agendamento via Central 135 e das outras medidas implantadas, as filas externas deixaram de existir. No ano de 2014 não foram registradas filas externas na APS Sobral. Contudo, os servidores foram firmes ao considerarem que na prática o que realmente houve foi a substituição das filas externas presenciais pelas filas virtuais, provenientes dos agendamentos realizados pelo sistema 135, mas com a considerável vantagem da garantia do atendimento no dia agendado pelo segurado, sem o drama das filas. Os 
ISSN 1981-3694

(DOI): $10.5902 / 1981369419593$

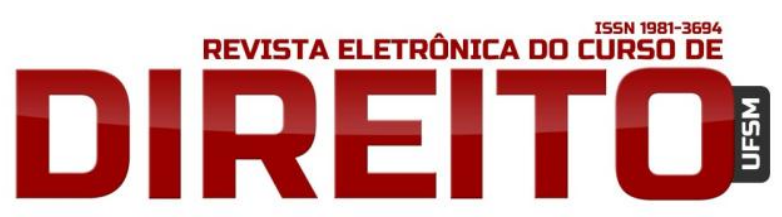

O PROCESSO DE MUDANÇAS ADMINISTRATIVAS E TECNOLÓGICAS QUE PÔS FIM ÀS FILAS NOS POSTOS DE ATENDIMENTO DA PREVIDÊNCIA SOCIAL

SIDNEY SOARES FILHO ROBSOn CELSO LEOCÁdIO TOTE

servidores apontaram também a modernização da agência e a tecnologia como fatores importantes para o fim das filas presenciais externas.

Infelizmente, um grande número de segurados ainda procura a APS de Sobral sem passar pelo prévio agendamento da Central 135. São os chamados atendimentos espontâneos, o que gera certo acúmulo de segurados no interior da agência à espera do atendimento. Segundo os servidores entrevistados, o público-alvo da agência de Sobral é formado por pessoas de baixa renda e de baixa escolaridade. Muitos ainda desconhecem, portanto, o sistema de agendamento telefônico e mais ainda o site da Previdência Social na Internet. Por não conhecerem esses serviços, os segurados se dirigem pessoalmente à agência e acabam apenas fazendo, pessoalmente, um agendamento - tendo que voltar na data futura agendada - que poderia ser feito por telefone.

Hoje, os primeiros segurados começam a chegar por volta das seis e meia da manhã. Não há filas externas nem entrega de senhas manuais. Todo o atendimento dentro da agência é monitorado eletronicamente pelo sistema SGA. Os agendamentos são marcados tanto para o período da manhã quanto para o da tarde, quando o movimento é bem menor. Todos os segurados que vão à agência são atendidos no dia. Ainda há muito atendimento espontâneo, sem agendamento prévio, fruto da falta de informação do segurado.

Através do controle realizado pela Sala de Monitoramento, o chefe em exercício da APS Sobral, Leonardo Benício, apresentou dados estatísticos do atendimento da agência, extraídos do sistema informatizado Plano de Ação 2014. Há dois indicadores importantes, o TMEA e o TMEAPM. O TMEA é o tempo médio de espera em dias para atendimento administrativo dentro do mês corrente após o agendamento pelo telefone 135 ou pela Internet. Por administrativo entende-se o atendimento a todos os serviços e benefícios, excetuando apenas a marcação de perícia médica. A planilha de metas compromissadas do indicador mostra, em quantidade de dias, o previsto e o realizado mês a mês. Assim, a gerência da agência acompanha o tempo médio de espera em dias para os agendamentos marcados no mês e o desempenho da APS em relação ao planejado.

O TMEA-PM é o tempo médio de espera em dias para atendimento de perícia médica dentro do mês corrente após o agendamento. A perícia médica tem um tratamento especial por ser um serviço bastante procurado pela sua condição sine qua non para a concessão de benefícios de incapacidade. Da mesma forma que o indicador administrativo, aqui o acompanhamento é mês a mês, com a comparação entre o previsto e o realizado. A planilha 
ISSN 1981-3694

(DOI): $10.5902 / 1981369419593$

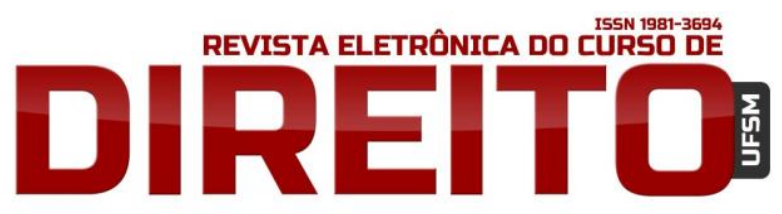

O PROCESSO DE MUDANCCAS ADMINISTRATIVAS E TECNOLÓGICAS QUE PÔS FIM ÀS FILAS NOS POSTOS DE ATENDIMENTO DA PREVIDÊNCIA SOCIAL

SIDNEY SOARES FILHO ROBSON CELSO LEOCÁDIO TOTE

abaixo traz os dados de 2014, o que possibilita uma visualização gráfica para melhor compreensão dos dois indicadores.

PAINEL DE DESEMPENHO 05.022.090 - APS SOBRAL

\begin{tabular}{|c|c|c|c|c|c|c|c|c|c|c|c|}
\hline \multicolumn{12}{|c|}{ METAS COMPROMISSADAS } \\
\hline Indicador & $P / R$ & Jan & Fev & Mar & Abr & Mai & Jun & Jul & Ago & Set & Out \\
\hline \multirow{2}{*}{ TMEA } & Previsto & 18 & 18 & 17 & 16 & 16 & 18 & 18 & 18 & 16 & 15 \\
\hline & Realizado & 9 & 15 & 10 & 9 & 14 & 17 & 29 & 23 & 13 & 16 \\
\hline \multirow{2}{*}{ TMEA - PM } & Previsto & 50 & 50 & 45 & 43 & 40 & 44 & 44 & 43 & 40 & 38 \\
\hline & Realizado & 38 & 38 & 37 & 34 & 38 & 42 & 30 & 29 & 30 & 38 \\
\hline
\end{tabular}

$\mathrm{P}=$ Previsto

$\mathrm{R}=$ Realizado

Fazendo uma análise dos dados oferecidos pelo sistema de monitoramento, pode-se constatar que a APS Sobral, considerando os agendamentos administrativos efetuados e atendidos dentro do próprio mês (TMEA), tem levado em média 15,5 dias para atender um segurado que agenda atendimento na APS pela Central 135, informação retirada da planilha acima, considerando o período de janeiro a outubro de 2014. O número fica abaixo do tempo médio previsto para o período, que foi de 17 dias. Um desempenho que foi considerado bem satisfatório pelo chefe da APS, apesar de nos meses de julho, agosto e outubro a meta prevista ter sido suplantada, conforme vemos no gráfico correspondente acima.

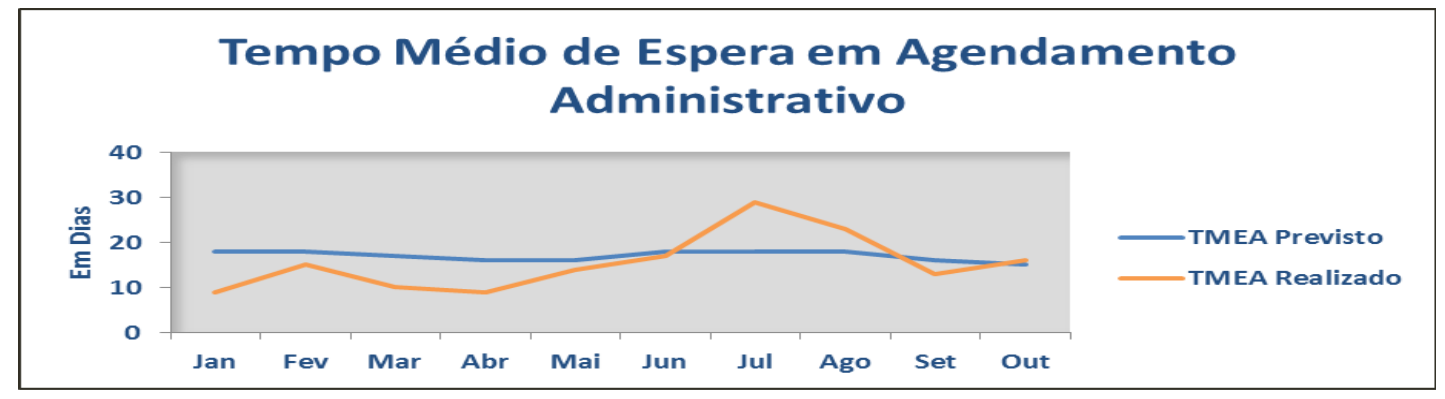

Quando analisado, por sua vez, o indicador TMEA-PM, através da mesma planilha e do gráfico logo acima, observa-se que, para o serviço de perícia médica, o tempo médio em dias para a realização do atendimento, no mesmo período, ficou satisfatoriamente abaixo do previsto em praticamente todos os meses. A realização de uma perícia médica agendada pela Central 135, na APS Sobral, está levando em média 35 dias, número avaliado como satisfatório pelo chefe da agência. 
Tempo Médio de Espera em Agendamento Perícia Médica

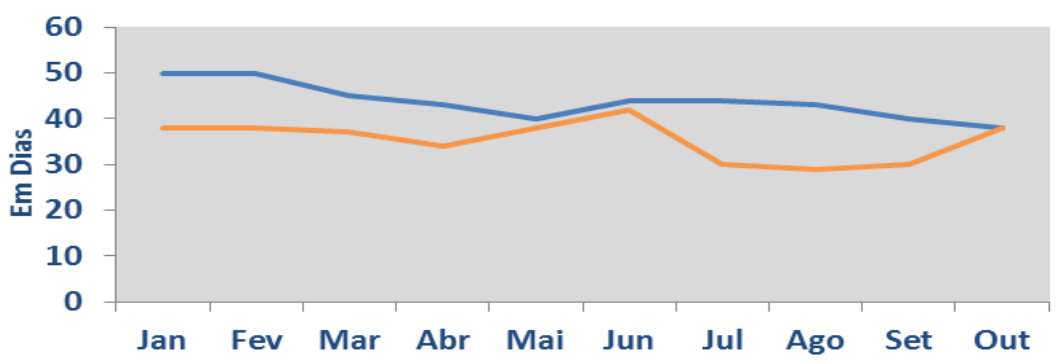

-TMEA - PM

Previsto

-TMEA - PM

Realizado

Para a gestão e o monitoramento do atendimento dentro da agência há dois outros indicadores, extraídos diariamente do sistema Sala de Atendimento do SGA: o TME e o TMA, tempo médio em espera e o tempo médio em atendimento, respectivamente. O TME apresenta o tempo médio decorrido entre o momento em que o segurado recebe sua senha eletrônica e o momento em que sua senha é chamada no painel digital. Já o TMA representa o tempo médio em que o segurado é atendido pelo servidor no seu guichê de atendimento individual. Os indicadores apresentam dados para atendimentos agendados (administrativos e periciais) e não agendados (espontâneos), além do destaque para atendimentos que levam mais de duas horas. A planilha abaixo apresenta dados de dezembro de 2014, com a respectiva visualização gráfica em seguida.

\begin{tabular}{|c|c|c|c|c|}
\hline \multirow{2}{*}{ Senhas } & \multicolumn{2}{|c|}{ Agendado } & \multirow{2}{*}{ Total } \\
\cline { 2 - 3 } & Perícias & $\begin{array}{c}\text { Administrati- } \\
\text { vo }\end{array}$ & & \\
\hline Distribuídas & 211 & 158 & 1.076 & 1.445 \\
\hline TME & $00: 53: 41$ & $00: 22: 23$ & $00: 38: 28$ & $00: 39: 08$ \\
\hline TMA & $00: 16: 23$ & $00: 31: 05$ & $00: 10: 37$ & $00: 14: 15$ \\
\hline Aguardaram $+2 h$ & 0 & 0 & 0 & 0 \\
\hline
\end{tabular}

. Atendimento Geral_- Periodo: 29/11/2014 a 08/12/2014 ... . 9 Dias

De acordo com os dados acima, nos nove dias considerados na pesquisa, o TME - Tempo Médio em Espera, para atendimento administrativo, ficou em torno de 22 minutos, e o TMA Tempo Médio no Atendimento, em torno de 31 minutos. Em se tratando de perícias médicas, o TME ficou em 53 minutos, e o TMA, em 16 minutos. Com relação aos atendimentos não agendados, o TME ficou em 38 minutos, e o TMA, em 10 minutos. Não houve ocorrência de segurado aguardando mais de duas horas. Todos os indicadores foram considerados dentro do esperado pela APS. O gráfico abaixo traduz visualmente a situação constatada pelos números. 
Tempo Médio de Espera e Tempo Médio em Atendimento 29/11/2014 a 08/12/2014 - 9 Dias

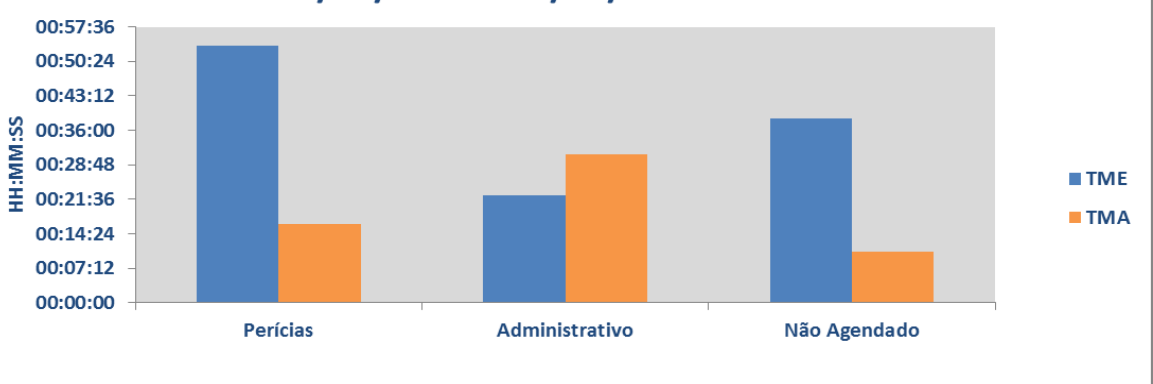

A partir do gráfico acima se pode deduzir situações que confirmam algumas informações fornecidas pelos servidores da APS. O baixo TMA para atendimentos não agendados é um indicativo de que muitos dos que vão a APS sem agendamento prévio vão apenas para agendar seu atendimento para uma futura data. Assim, um deslocamento à agência poderia ser eliminado com o uso da Central 135. Os segurados esperam um tempo maior na APS para serem atendidos pelos médicos, mas, uma vez diante do perito, o atendimento pode ser considerado dentro do esperado, em torno de 15 minutos, como vimos. Os atendimentos administrativos levando em média 30 minutos indicam o tempo para o entendimento do caso, a análise documentalística, verificação nos cadastros eletrônicos e outras providências tomadas pelo servidor diante do segurado.
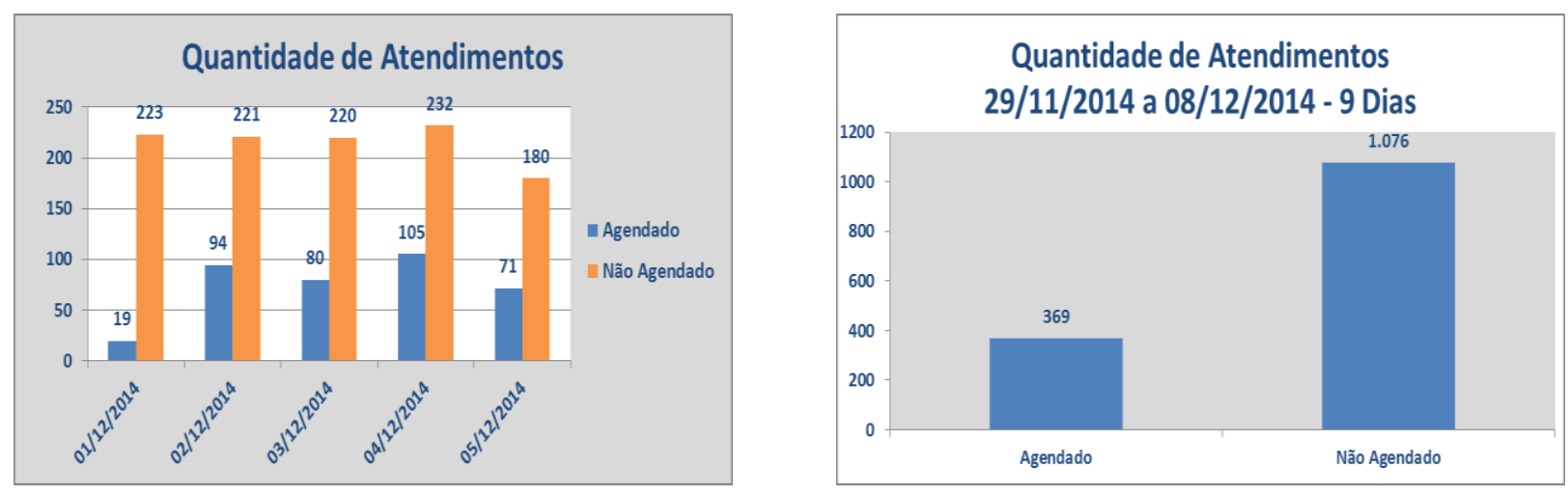

Os dois gráficos acima revelam visualmente a grande quantidade de atendimentos não agendados pela central ou pela Internet, o triplo. São os chamados atendimentos espontâneos ou demanda espontânea, cidadãos que procuram a APS pelos mais diversos motivos, como informações e dúvidas. De acordo com os servidores, isso ocorre em função do perfil de baixa 
ISSN 1981-3694

(DOI): $10.5902 / 1981369419593$

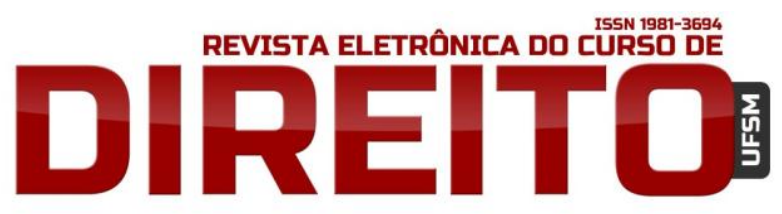

O PROCESSO DE MUDANCAS ADMINISTRATIVAS E TECNOLÓGICAS QUE PÔS FIM ÀS FILAS NOS POSTOS DE ATENDIMENTO DA PREVIDÊNCIA SOCIAL

SIDNEY SOARES FILHO ROBSON CELSO LEOCÁDIO TOTE

renda e baixa escolaridade do público-alvo da APS de Sobral. Muitos desconhecem o serviço de agendamento telefônico e não dispõem de acesso a computadores. Mas, por outro lado, esses números também revelam um dado de muita importância: a necessidade de maior divulgação desses serviços, principalmente do agendamento telefônico, o mais acessível a toda a comunidade.

Este autor foi também à agência Fortaleza Sul, localizada no bairro Edson Queiroz, na capital cearense. No dia 22 de dezembro de 2014, às 7 horas, havia em torno de 15 pessoas em fila esperando a abertura da agência. Todos haviam chegado na manhã do mesmo dia e optaram por chegar cedo, ou seja, antes da abertura da APS, na expectativa de estarem entre os primeiros a serem atendidos.

Esta agência, antigamente localizada no centro de Fortaleza, passou por todo o processo de tratamento e eliminação das filas, testemunhado pelo servidor Antônio Francismar Lucena Lopes, chefe desta unidade desde o período crítico das filas nas madrugadas do centro. Francismar relatou que a fila na agência, quando localizada no centro, começava a se formar por volta das 22 horas do dia anterior. As pessoas vinham para dormir na fila. Eram comuns as brigas e os assaltos. Havia a figura do vendedor de lugar na fila. Outro elemento também comum àquela época nesta agência era o atravessador despachante. No dia seguinte nem todos eram atendidos, pois a quantidade de senhas era limitada.

A realidade hoje é outra. Segundo Francismar, a fila agora é virtual, formada a partir do uso do sistema de agendamento da Central 135, mas com o diferencial importante de garantir o direito ao atendimento naquela data e hora marcadas, possibilitando ao segurado aguardar em casa - normalmente até 30 dias da sua ligação telefônica - o dia de ser atendido pelo INSS. Hoje, todos os que vão à agência são atendidos no mesmo dia, e não há mais registros de filas externas, salvo aquelas formadas momentos antes da abertura da agência.

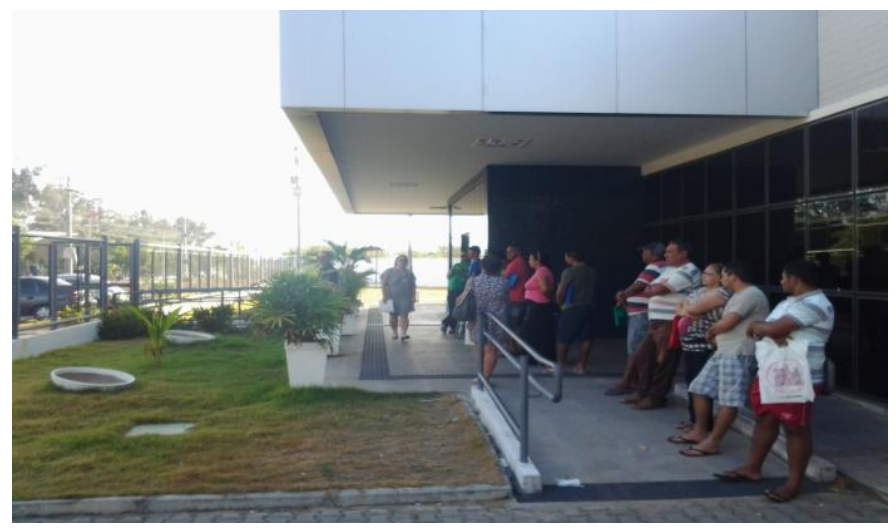


ISSN 1981-3694

(DOI): $10.5902 / 1981369419593$

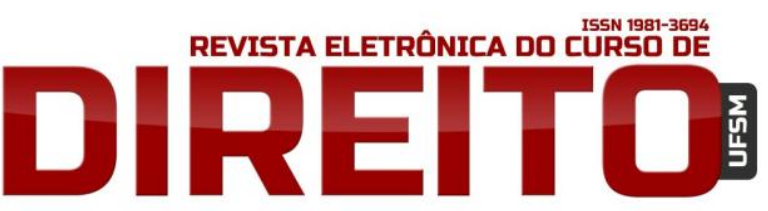

O PROCESSO DE MUDANCAS ADMINISTRATIVAS E TECNOLÓGICAS QUE PÔS FIM ȦS FILAS NOS POSTOS DE ATENDIMENTO DA PREVIDÊNCIA SOCIAL

SIDNEY SOARES FILHO ROBSON CELSO LEOCÁDIO TOTE

O horário do agendamento é respeitado pela agência no dia do atendimento e poucas vezes se ultrapassam 15 minutos da hora marcada, até para não comprometer os indicadores de desempenho da unidade. Há agendamentos marcados também para a parte da tarde. Abaixo, segue foto da agência Fortaleza Sul antes de sua abertura, às 07:00 h, em 22 de dezembro de 2014.

A soma dos esforços iniciais de escoamento das filas externas e dos esforços de consolidação da mudança, apresentados nesta seção, gerou resultados que mudaram a história da Previdência Social brasileira. Alguns desses resultados foram apresentados graficamente, a partir de dados de âmbito nacional, por Rogério Pacheco Jordão ${ }^{30}$.

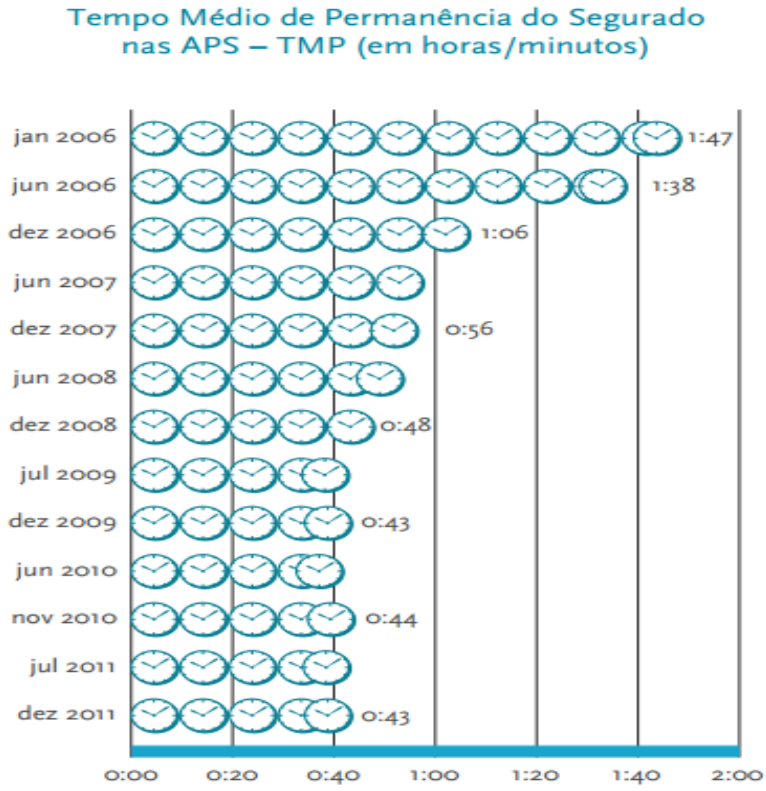

Com base nos dados coletados pelos sistemas de acompanhamento do agendamento e atendimento e, a partir de 2010, pelas Salas de Monitoramento, vê-se nos dois gráficos a evolução do Tempo Médio de Permanência do Segurado na APS e do Tempo Médio de Atendimento Agendado, de janeiro de 2006 a dezembro de 2011, números que demonstram o efeito positivo das ações implementadas.

Contudo, o modelo de atendimento atual do INSS permanentemente tem novos desafios a serem superados, pois, mesmo com todos os avanços, tem sido alvo de críticas, e a imprensa tem noticiado problemas em agências ou até no complexo de atendimento como um todo,

30 JORDÃO, Rogério Pacheco. A virada da Previdência Social: como acabaram as filas nas portas das agências. 1. ed. Brasília: DATAPREV, 2013. p.56. 
relacionados com a demora para atender, sistemas informatizados fora de serviço, tecnologia, poucos servidores e filas de espera, algumas vezes vinculados a eventos particulares e específicos de um período do ano ou região.

Correio Braziliense 07/01/2014 ${ }^{31}$

Brasileiros enfrentam filas e má vontade em agências do INSS. Essa foi a realidade de quem procurou atendimento em um dos postos da instituição ontem. (...). Sistema lento, longas filas e falta de agentes administrativos e de peritos médicos. Essa é a realidade com a qual se depara quem precisa ir a uma das 1.688 agências do Instituto Nacional do Seguro Social (INSS). (...) Os mais de 240 mil brasileiros que procuraram um dos postos da Previdência Social ontem se depararam com a rede digital do instituto praticamente inoperante e com muita espera.

Campo Grande News 08/01/2014 32

Agências do INSS estão lotadas e espera na fila pode chegar a 4 horas. Aposentados e contribuintes que procuraram o INSS (Instituto Nacional do Seguro Social) em Campo Grande precisaram ter paciência: desde segunda-feira (6), as quatro agências estão lotadas, o tempo de espera é longo e, sobrecarregado, o sistema interno oscila e, a intervalos, fica fora do ar e não é possível concluir os atendimentos. Espera - 0 reajuste do salário mínimo para 2014, somado à volta do recesso do fim de ano são os responsáveis pela superlotação das agências, informa a assessoria de imprensa do Instituto.

O acompanhamento diário do atendimento através dos recursos tecnológicos já em uso, como a Sala de Monitoramento e o monitoramento da rede de comunicação e dos sistemas de informação, é fundamental para a identificação do problema e para a busca de uma solução rápida e eficaz. Nesse sentido também opina Rogério Pacheco Jordão (2013, p.54):

Havia em 2006-2007 e ainda há enormes desafios a serem superados, para os quais uma atenção permanente, diária, à gestão é necessária. Isto vale para qualquer organização que lide com o público e ainda mais para a Previdência Social, cujas agências recebem mais de 200 mil brasileiros todos os dias. Um pequeno problema pode tomar grandes proporções por conta do número de pessoas atendidas. Um sistema que fique fora do ar, um desvio não corrigido no processo de trabalho ou até um fator externo como a queda de um circuito de telecomunicação, que interliga a Agência da Previdência Social com os sistemas previdenciários, podem prejudicar a vida de milhares de segurados.

Há, portanto, o reconhecimento por parte do Instituto da importância do acompanhamento em tempo real de toda esta engenharia instalada a serviço do atendimento ao segurado, que devido a sua grandiosidade e diversidade estará sujeita a intempéries.

\footnotetext{
${ }^{31}$ Correio Brasiliense. Brasileiros enfrentam filas e má vontade em agências do INSS. Disponível em: < http://www.correiobraziliense.com.br/app/noticia/economia/2014/01/07/internas_economia,406609/br asileiros-enfrentam-filas-e-ma-vontade-em-agencias-do-inss.shtml.>. Acesso em: 08 agosto 2015.

32 Campo Grande NEWS. Agências do INSS estão lotadas e espera na fila pode chegar a 4-horas. Disponível em: < http://www.campograndenews.com.br/cidades/capital/agencias-do-inss-estao-lotadase-espera-na-fila-pode-chegar-a-4-horas.>. Acesso em: 08 agosto 2015.
} 


\section{CONCLUSÃO}

A Previdência Social esteve diante de um problema que parecia não ter solução. Até o ano de 2005 as agências de atendimento tentaram conviver com grandes filas de segurados em suas portas, às vezes formadas na noite do dia anterior. O INSS não tinha controle sobre essas filas, nem o conhecimento de suas particularidades. A imagem do Instituto era massacrada pela imprensa. Em algumas unidades, as filas se estendiam por quarteirões. 0 serviço era deficiente, pois muitos segurados voltavam para casa sem serem sequer ouvidos, e os benefícios levavam longo tempo para serem concedidos. Não havia gestão sobre o perfil da demanda. Os funcionários se queixavam de mal tratamento por parte do cidadão. Estavam descontentes, desmotivados, e a quantidade de servidores era reduzida. Este era o cenário no qual o atendimento estava inserido.

As causas identificadas para o fenômeno das filas foram o aumento da população com cobertura previdenciária em virtude do envelhecimento do povo brasileiro e do crescimento da população ativa, um quadro de servidores reduzido e acomodados, dez anos sem concursos públicos até 2003, o insucesso da terceirização no atendimento, que foi descontinuada em 2003, defasagem tecnológica, estrutura organizacional inadequada e ausência de gestão e indicadores.

A primeira tentativa de estudar o problema ocorreu em 2003, na cidade de São Paulo, palco do Projeto denominado PGA - Projeto de Gestão do Atendimento e abrangeu cinco agências de atendimento. Consultores do próprio Instituto fizeram um diagnóstico do atendimento e propuseram ações e correções que seriam aproveitadas futuramente.

Em 2005 inicia-se de fato o processo de mudança. Nélson Machado assume o Ministério da Previdência Social, com o objetivo de acabar com as filas nas agências, tarefa especialmente lhe confiada pelo Presidente Lula. Ambos entendem que a solução passa pela valorização do servidor e pela profissionalização da gestão.

Com o fim das filas estabelecido como objetivo prioritário, as primeiras ações de gestão são logo tomadas pela nova equipe. Uma série de alterações na estrutura e no organograma do INSS é executada, sendo a mais importante delas o deslocamento da área de arrecadação e fiscalização para a Receita Federal, deixando o Instituto responsável exclusivamente pelo 
ISSN 1981-3694

(DOI): $10.5902 / 1981369419593$

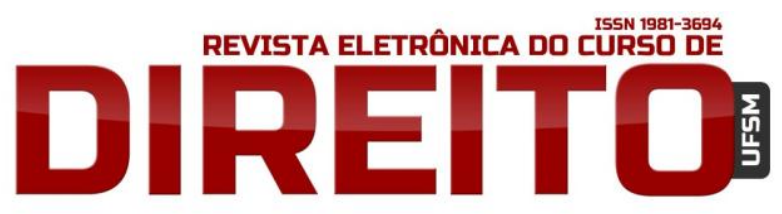

O PROCESSO DE MUDANÇAS ADMINISTRATIVAS E TECNOLÓGICAS QUE PÔS FIM ÀS FILAS NOS POSTOS DE ATENDIMENTO DA PREVIDÊNCIA SOCIAL

SIDNEY SOARES FILHO ROBSON CELSO LEOCÁDIO TOTE

negócio benefícios. Algumas medidas operacionais são também imediatamente postas em prática, como a expansão do horário de atendimento das agências.

No início do ano seguinte, o Presidente Lula promete ao povo brasileiro, diante da imprensa, acabar com as filas em três messes. Em maio, órgãos da mídia vão às agências e veiculam que nada mudou, e as filas continuam. A repercussão negativa do problema é ainda maior para autoridades e instituições. Nesse período e diante do cenário mais desfavorável, a Gerência Regional Nordeste lança em Recife o Projeto Madrugada sem Filas.

O Projeto Madrugada sem Filas tinha como objetivo combater as filas nas Agências da Previdência Social, que varavam a madrugada em Recife e Olinda, e como missão não permitir que qualquer pessoa passasse a noite na fila ou tivesse que comprar senha para conseguir o atendimento. Assim, as agências passam a abrir às 5 horas, utilizando servidores voluntários. São ministradas palestras de conscientização aos segurados, abordando inclusive o novo serviço de agendamento, e é realizado um diagnóstico das filas. 0 projeto cumpre seu objetivo, e em um mês as filas acabam nas APS das cidades de Recife e Olinda.

Estamos em 2006 e em junho é inaugurada em Recife a primeira Central de Atendimento 135, trazendo consigo o serviço que determina o fim das filas externas presenciais em todo o país: o agendamento do atendimento. Com o novo modelo de atendimento, o segurado telefona para a central e agenda sua ida a APS de sua escolha, comparecendo no dia e horário determinados, com o direito de atendimento garantido e sem filas externas. 0 serviço de agendamento pela Central 135 foi o principal fator responsável pelo fim das filas presenciais externas.

A modernização tecnológica foi imprescindível para dotar a Previdência Social de uma infraestrutura compatível com as demandas exigidas pelo novo modelo de atendimento, que estava em plena implantação. Em 2005 são implantados o SGA - Sistema de Gerenciamento de Atendimento, que controla a distribuição eletrônica de senhas e todo o atendimento presencial na APS e o SAE - Sistema de Agendamento Eletrônico, cuja finalidade é prover a comunicação final entre a APS e o teleatendimento da Central 135. Em 2006, A grande maioria dos links de comunicação de dados entre as agências, gerências e centrais de atendimento espalhadas pelo país passa para $256 \mathrm{Kbps}$. Em algumas agências maiores nos estados, chegam a $512 \mathrm{Kbps}$, e $1 \mathrm{Mbps}$ em agências maiores, nas capitais. Além disso, entre 2005 e 2008 há a renovação do parque de equipamentos, como impressoras e estações de trabalho. As 50 mil máquinas do INSS são substituídas. 
ISSN 1981-3694

(DOI): $10.5902 / 1981369419593$

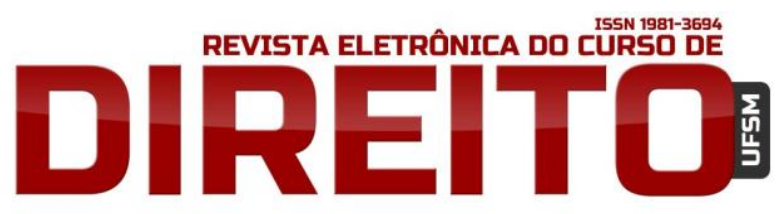

O PROCESSO DE MUDANÇAS ADMINISTRATIVAS E TECNOLÓGICAS QUE PÔS FIM ÀS FILAS NOS POSTOS DE ATENDIMENTO DA PREVIDÊNCIA SOCIAL

SIDNEY SOARES FILHO ROBSON CELSO LEOCÁDIO TOTE

Depois de todas essas medidas tomadas a partir de 2005, o INSS vê em dois anos as filas sendo gradativamente eliminadas em todo o país, fenômeno que ficaria conhecido como a "virada" da Previdência Social. O Instituto pode, portanto, finalmente anunciar que o problema das enormes filas externas nas madrugadas havia acabado.

Em 2008 as APS se modernizam também fisicamente para se adequarem ao novo modelo de atendimento. Assim, o INSS lança a Resolução INSS/PRESS n 62, de 09 de dezembro de 2008 DOU de $11 / 12 / 2008^{33}$, que aprovou o Manual de Procedimentos para Adequação da Infraestrutura das Agências da Previdência Social. O objetivo é adequar e padronizar o modelo estrutural, visual e de atendimento em todas as APS. A resolução determina ainda que as agências devem obedecer ao Manual de Identidade Visual da Previdência Social, em sua $8^{a}$ e última edição, publicada em Janeiro de 2008, que trouxe o visual externo e interno que as Agências da Previdência Social mantêm até hoje. No mesmo ano inicia-se o Plano de Expansão, que visa dotar todas as cidades acima de 20 mil habitantes com uma APS.

Em 2009, após o aumento da base de dados certificada do Cadastro Nacional de Informações Sociais (CNIS), essencial na hora de o INSS conceder um benefício, o Instituto passa a adotar o reconhecimento automático de direito, considerando como verdadeiras todas as informações constantes neste banco de dados, referentes aos vínculos e contribuições do segurado, o que fica conhecido como Inversão do ônus da Prova. Isso contribui decisivamente para a agilidade na hora da concessão do benefício, e nesse mesmo ano a imprensa já divulga a concessão de aposentadoria em 30 minutos, um marco.

Outra ação importante no pós-filas é a criação, em 2010, das Salas de Monitoramento, que proporcionam um acompanhamento em tempo real do atendimento em todas as APS do país. A partir dos dados coletados automaticamente a cada 15 minutos pelos seus sistemas informatizados, as Salas de Monitoramento fornecem aos chefes e aos servidores das agências indicadores valiosos que revelam como está sendo a produtividade do trabalho, elementos importantes para a melhoria no atendimento.

Baseado no que este autor pôde constatar presencialmente, nos relatos e dados obtidos dos servidores nas duas APS visitadas, em algumas matérias jornalísticas e nas particularidades do novo modelo de atendimento, este trabalho conclui também que as filas de espera na

\footnotetext{
${ }^{33}$ MPS. Manual de Procedimentos para Adequação da Infraestrutura das Agências da Previdência Social. Brasília: MPS, 2008.
} 
ISSN 1981-3694

(DOI): $10.5902 / 1981369419593$

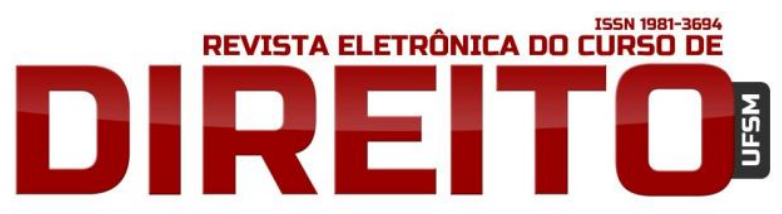

O PROCESSO DE MUDANÇAS ADMINISTRATIVAS E TECNOLÓGICAS QUE PÔS FIM ÀS FILAS NOS POSTOS DE ATENDIMENTO DA PREVIDÊNCIA SOCIAL

SIDNEY SOARES FILHO ROBSON CELSO LEOCÁDIO TOTE

Previdência Social deixaram de ser presenciais externas para serem virtuais, ou seja, filas eletrônicas organizadas a partir do sistema de agendamento por telefone ou pela Internet.

Esta constatação em nada deprecia o trabalho de autoridades, gestores e servidores e o valor da conquista histórica da extinção das dramáticas filas externas nas madrugadas das agências. Ao contrário, a estrutura de atendimento baseada nas filas virtuais assegura ao cidadão o direito de ser atendido em determinado dia e em determinado horário na APS de sua escolha, aguardando em casa a data certa de comparecimento no INSS, sem a necessidade de chegar à noite anterior ou madrugada do dia do atendimento para evitar longas filas. Além disso, chegando à APS, o segurado aguarda dentro da agência, onde encontra instalações adequadas, modernizadas, confortáveis.

O desafio do INSS hoje é reduzir o tempo médio de espera para atendimento (TMEA), que é o tempo em dias entre a solicitação de agendamento e o dia agendado. Em outras palavras, reduzir as filas virtuais. Na APS de Sobral, por exemplo, esse tempo foi de 15 dias em média no ano passado. Esse novo objetivo passa por uma série de fatores e variáveis que influenciam no atendimento dentro das APS, como quantidade de servidores, médicos, desempenho dos sistemas de informação e das redes de transmissão de dados, características da demanda, treinamento, quantidade de pontos de atendimento, dentre outros. O TMEA nacional em janeiro de 2006 era de 95 dias, ao passo que em dezembro de 2011 já havia caído para 21 dias, demonstrando o reconhecimento da importância da questão e o empenho do Instituto no seu tratamento. A Sala de Monitoramento e seus indicadores têm importante função nesse esforço.

O sistema de atendimento atual ocupa-se de uma grande quantidade de atendimentos espontâneos nas agências do INSS. Muitas pessoas ainda não conhecem o serviço de agendamento pela Central 135 ou pelo site do Instituto, deslocando-se sem agendamento às agências, o que quer dizer, sem uma orientação prévia sobre seu problema ou solicitação, tornando muitas vezes pouco produtiva aquela ida ao posto de benefício. Um programa de divulgação do serviço de agendamento deveria ser desenvolvido pelo Instituto, fazendo uso dos meios de comunicação de massa disponíveis.

Apesar dos avanços alcançados, o modelo atual de atendimento ao segurado do INSS tem sido alvo de críticas por parte da imprensa. Alguns veículos têm noticiado agências fora do ar, escassez de servidores, sistemas lentos e longa espera para atendimento dentro da APS. O Instituto tem mantido permanente acompanhamento e monitoramento de todo o sistema na busca de identificar e tratar tais problemas, mas o atendimento previdenciário é complexo, grandioso e diversificado, o que o torna de fato vulnerável a eventos que desencadeiem 
ISSN 1981-3694

(DOI): $10.5902 / 1981369419593$

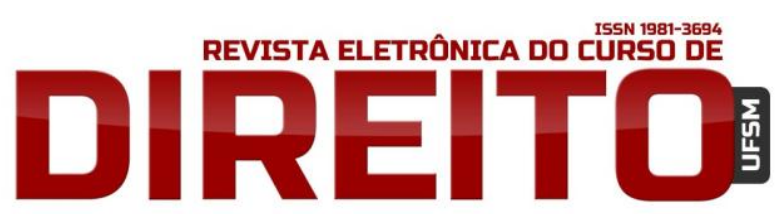

O PROCESSO DE MUDANCAS ADMINISTRATIVAS E TECNOLÓGICAS QUE PÔS FIM ÀS FILAS NOS POSTOS DE ATENDIMENTO DA PREVIDÊNCIA SOCIAL

SIDNEY SOARES FILHO ROBSON CELSO LEOCÁDIO TOTE

problemas em seu funcionamento. Contudo, trata-se de situações especiais e particulares que não comprometem o conquistado estágio atual do serviço oferecido ao segurado e não se comparam com a realidade anterior das permanentes filas externas nos postos de benefícios. Prever e lidar com essas situações atípicas é o novo desafio do INSS no modelo atual de atendimento.

Portanto, a "virada” aconteceu. Graças à vontade política, à gestão profissional, ao esforço conjunto dos servidores e à tecnologia, as longas filas presenciais nas portas das Agências da Previdência Social acabaram. Hoje as filas são virtuais e monitoradas pelos mecanismos de gestão e pelas próprias agências, visando garantir ao segurado o seu direito a um atendimento mais humano, em dia e horário previamente agendados, na unidade de sua escolha, para onde se deslocará devidamente orientado.

\section{REFERÊNCIAS}

BRASIL. Constituição (1988). Constituição da República Federativa do Brasil. Brasília: Senado Federal.

BRASIL. Resolução INSS/PRESS N 62, DE 09 de dezembro de 2008 - DOU DE 11/12/2008.

Campo Grande NEWS. Agências do INSS estão lotadas e espera na fila pode chegar a 4-horas. Disponível em: < http://www.campograndenews.com.br/cidades/capital/agencias-do-inssestao-lotadas-e-espera-na-fila-pode-chegar-a-4-horas.>. Acesso em: 08 agosto 2015.

IBRAHIM, Fábio Zambitte. Curso de Direito Previdenciário.17. ed. Rio de Janeiro: Impetus, 2012.

CASTRO, Carlos Alberto Pereira de. Manual de Direito Previdenciário. 15.ed. Rio de Janeiro: Forense, 2013.

Correio Brasiliense. Brasileiros enfrentam filas e má vontade em agências do INSS. Disponível em: <

http://www.correiobraziliense.com.br/app/noticia/economia/2014/01/07/internas_economia,4 06609/brasileiros-enfrentam-filas-e-ma-vontade-em-agencias-do-inss.shtml.>. Acesso em: 08 agosto 2015.

JORDÃO, Rogério Pacheco. A virada da Previdência Social: como acabaram as filas nas portas das agências. 1. ed. Brasília: DATAPREV, 2013.

LOPES, João Maria. Fila: solução no passado, desafio no presente, diferencial no futuro. 1. ed. Natal: JLCH2, 2007.

MPS. Manual de Identidade Visual da Previdência Social. 8 ed. Brasília: MPS, 2008 
ISSN 1981-3694

(DOI): $10.5902 / 1981369419593$

REVISTA ELETRÔNICA DO CURSD DE

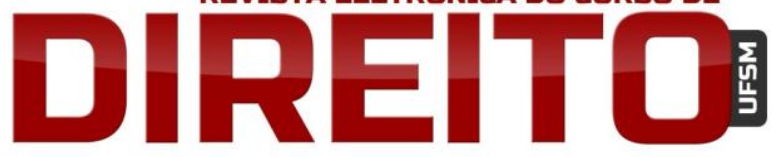

O PROCESSO DE MUDANÇAS ADMINISTRATIVAS E TECNOLÓGICAS QUE PÔS FIM ÀS FILAS NOS POSTOS DE ATENDIMENTO DA PREVIDÊNCIA SOCIAL

SIDNEY SOARES FILHO ROBSON CELSO LEOCÁDIO TOTE

MPS. Manual de Procedimentos para Adequação da Infraestrutura das Agências da Previdência Social. Brasília: MPS, 2008.

PESSOA, Eudes André. A Constituição Federal e os Direitos Sociais Básicos ao Cidadão Brasileiro. Disponível em: <http://www.ambitojuridico.com.br/site/index.php?n_link=revista_artigos_leitura\&tartigo_id=9623>. Acesso em: 06 ago. 2015.

Recebido em: 23/09/2015 / Revisões requeridas em: 24/11/2015 / Aprovado em: 16/12/2015 